DOI: $10.12731 / 2658-6649-2021-13-2-225-236$

UDC 611.013.11

\title{
MORPHOLOGICAL FEATURES OF SPERMATOZOA FROM MALE WHITE RATS UNDER EXPERIMENTAL STRESS
}

\section{I.Yu. Arestova, E.G. Sharonova, M.Yu. Kupriyanova}

We present the effect of stressogenic factors on the morphological parameters of spermatozoa.

Objective. We studied the morpho-physiological features of spermatozoa from male albino rats under experimental stress.

Materials and methods. A experiment was carried out using sexually mature outbred white rats. Combined stress was performed to an experimental group: after three days of starvation, an emotional stress of "free swimming in a cage" technique was provided. Under a microscope, the spermatozoa were counted per volume of epididymal suspension, the activity was evaluated, and the morphology was studied.

Results. A study of the epididymal suspension of male rats under starvation and "emotional" stress showed a decrease in the total number of spermatozoa and sperm motility indices, and an increase in the abnormal gamete forms compared to the control.

Conclusion. The combined effect of even short-term stressogenic factors leads to significant changes in the spermogram, allowing the quantitative and qualitative seminal fluid parameters to be a convincing criterion of maladaptation processes in the body under the stress.

Keywords: stress; spermatogenesis; spermogram; morphology

For citation. Arestova I.Yu., Sharonova E.G., Kupriyanova M.Yu. Morphological features of spermatozoa from male white rats under experimental stress. Siberian Journal of Life Sciences and Agriculture, 2021, vol. 13, no. 2, pp. 225-236. DOI: $10.12731 / 2658-6649-2021-13-2-225-236$

\section{МОРФОЛОГИЧЕСКИЕ ОСОБЕННОСТИ СПЕРМАТОЗОИДОВ САМЦОВ БЕЛЫХ КРЫС В УСЛОВИЯХ ЭКСПЕРИМЕНТАЛЬНОГО СТРЕССА}

\section{И.Ю. Арестова, Е.Г. Шаронова, М.Ю. Куприянова}

Представлены результаты исследования влияния стрессогенных факторов на морфологические параметры сперматозоидов.

Цель. Изучение особенностей морфо-физиологии сперматозоидов самиов белых крыс в условиях экспериментального стресса. 
Материалы и методы. Проведен эксперимент с использованием половозрелых беспородных бельх крыс. Экспериментальная группа животных подвергалась комбинированному стрессу: трое суток - голод, по истечении третьих суток - эмоциональный стресс, в соответствии с методикой «свободное плавание в клетке». Подсчитывали количество сперматозоидов в единице объема эпидидимальной взвеси, проводилась оценка активности под микроскопом, изучалась морфология.

Результаты. Исследование эпидидимальной взвеси самцов, перенесших голод и «эмоииональный» стресс, показало снижение общего числа сперматозоидов и показателей подвижности сперматозоидов у подопытных крыс по сравнению с контрольными животными, а также увеличение у них патологических форм гамет.

Заключение. Установлено, что даже незначительное по времени, но комбинированное воздействие стрессогенных факторов приводит к существенным изменениям спермограммы, а количественные и качественные параметры семенной жидкости могут служить убедительным критерием дезадаптационных процессов, происходящих в организме под влиянием стресса.

Ключевые слова: стресс; сперматогенез; спермограмма; морфология

Для цитирования. Арестова И.Ю., Шаронова Е.Г., Куприянова М.Ю. Морфологические особенности сперматозоидов самиов белых крыс в условиях экспериментального стресса // Siberian Journal of Life Sciences and Agriculture. 2021. T. 13, № 2. C. 225-236. DOI: 10.12731/2658-6649-2021-13-2-225-236

\section{Introduction}

A significant number of clinical observations and experiments confirm the increase of spermatogenesis disorders in modern men [11], [16].

The scientists assess the quality of the ejaculate based on the World Health Organization recommendations [15]. However, the assessment of sperm morpho-physiology is the subject of debate [1]. The data on morpho-functional characteristics of male germ cells under stress conditions differ. This may show that spermatozoa are very sensitive to various factors. Different factors can affect the spermatogenesis and morphology of spermatozoa: physical [19], chemical [7], [24], food [2], biological [8], and social [23], [10].

The effect of stress on spermatogenesis is studied poorly. Studies of the role of damaging factors mainly concern female reproductive function. The ethical component undoubtedly complicated the study of stress factors in spermatogenesis. The stressor component cannot be distinguished easily. However, there is experimental evidence confirming the relationship between stress and impaired spermatogenesis [3], [4], [9]. 
The purpose of our study was to study the morpho-physiological features of spermatozoa from male albino rats under experimental stress.

\section{Research materials and methods}

An experiment was carried out using mature male outbred white rats weighing from 250 to $320 \mathrm{~g}$.

The animals were allocated according to the principle of analogues in control and the experimental groups, 10 animals each. The sample size is small because the study is a pilot one to determine the feasibility of further studies.

The experiment on the animals was conducted in accordance with the "Guidelines for accommodation and care of animals. Species-specific provisions for laboratory rodents and rabbits" (GOST 33216-2014) and the "European Convention for the Protection of Vertebrate Animals used for Experimental and Other Scientific Purposes" [18].

The experiment lasted for 3 days. The animals of the second experimental group were kept in the absence of food, but with free access to water, experiencing starvation stress. At the end of the third day, all animals of the experimental group were additionally subjected to emotional stress, according to the "free swimming in the cage" technique (animals swam for 3 hours in a plastic aquarium filled with water of $22-24^{\circ} \mathrm{C}$ ).

The control group of animals was intact; the animals were kept in the vivarium, had free access to water and received food in accordance with the regulations.

After three days, all animals were removed from the experiment. The animals were terminated using humane and ethically justified methods.

Testes of rats were examined in the control (10 animals) and the experimental (10 animals subjected to combined stress) groups. To get mature spermatozoa, testicular appendages were cut in $1 \mathrm{~mL}$ of $5 \%$ glucose solution at $37^{\circ} \mathrm{C}$. Then, the appendage was freed from the spermatozoa using a sterile rubber tube [5], [6].

The following parameters were evaluated: the spermatozoa count per volume of epididymal suspension in a hemocytometer (Goryaev chamber); the activity, and the morphology under a microscope. For the micromorphological analysis, 200 sperm cells were counted and measured in stained smears in duplicate. Among the counted germ cells, the percentage of abnormal cells was determined, and the TeratoZoospermia Index (TZI) was calculated as the ratio of the total number of abnormalities detected to the number of abnormal spermatozoa. Sperm smears were studied using a MIKMED-6 light-optical microscope with video-visualization. Images were imported and analyzed using "Micro View” morphometric analysis software (LOMO-Microsystems, SPb, Russia). 
The significance of the results in the small sample was tested by nonparametric Mann-Whitney criterion. The values are given as $\mathrm{M} \pm \mathrm{s}$ (M, mean; $\mathrm{s}$, standard error). The critical level of significance for differences between the means was set as $\mathrm{p}=0.05$.

\section{Results and discussion}

The data got show that the total number of sperm cells in the male control rats per volume of epididymal suspension was $17.19 \pm 0.52 * 10^{6}$, which is $35.25 \%$ more than in the stressed males $(\mathrm{p}<0.05)$ (Table 1$)$.

Table 1.

Indicators of epididymal suspension

\begin{tabular}{|c|c|c|c|}
\hline \multirow[b]{2}{*}{ Indicators } & \multicolumn{2}{|c|}{ Group } & \multirow{2}{*}{$\begin{array}{c}\text { Difference } \\
\text { between } \\
\text { groups, \% }\end{array}$} \\
\hline & $\begin{array}{l}\text { Control } \\
(n=10)\end{array}$ & $\begin{array}{c}\text { Experimental } \\
(n=10)\end{array}$ & \\
\hline Sperm count, $\mathrm{mln} / \mathrm{ml}$ & $17,19 \pm 0,52$ & $11,13 \pm 0,81$ & $35,25^{*}$ \\
\hline Number of motile sperm, $\mathrm{mln} / \mathrm{ml}$ & $8,44 \pm 0,33$ & $7,18 \pm 0,16$ & $14,93 *$ \\
\hline The number of actively moving, $\mathrm{mln} / \mathrm{ml}$ & $4,53 \pm 0,52$ & $2,73 \pm 0,57$ & $40,18^{*}$ \\
\hline Number of dead per 200 cells & $15,40 \pm 0,97$ & $29,50 \pm 0,57$ & $47,80 *$ \\
\hline
\end{tabular}

Note: hereinafter $*$ - statistically significant $(p<0,05)$

Microscopic examination of the epididymal suspension of males exposed to starvation and "emotional" stress showed a decrease in sperm motility. Thus, the number of motile germ cells in experimental males was $7.18 \pm 0.16^{*} 10^{6}$, while in the intact group it was $8.44 \pm 0.33^{*} 10^{6}(\mathrm{p}<0.05)$.

Actively moving of all motile spermatozoa counted in the studied samples of epididymal suspension $53.68 \pm 2.51 \%$ in control and $37.68 \pm 3.15 \%$ in experimental group $(\mathrm{p}<0.05)$.

An index that affects fertility is the viability of spermatozoa. To assess the viability of spermatozoa, we counted the number of dead ones per 200 cells. Dead spermatozoa were detected after staining smears of homogenate with eosin.

The number of dead spermatozoa in homogenate smears was higher in the experimental group compared with the control. Thus, the number of dead cells in the control was $7.7 \pm 0.75 \%$, while in the stressed males it was $14.75 \pm 1.48 \%(\mathrm{p}<0.05)$.

At the time of the study, the content of viable gametes in control and experimental animals was $92.3 \pm 0.68$ and $85.3 \pm 1.34 \%$, respectively $(\mathrm{p}<0.05)$.

The pathological gametes were also noted in both control and experimental rats. Among the abnormalities, head, neck, middle part, and tail defects were noted.

The most common abnormalities of morphology were the end of the flagellum as a loop and a cytoplasmic drop on the flagellum (Table 2). From all 
abnormal sperm in samples of control animals, these deviations accounted for $6.07 \pm 0.52$ and $6.33 \pm 0.38 \%$ in control, and $8.48 \pm 0.45(p<0.05)$ and $6.76 \pm 0.7 \%$ $(\mathrm{p}>0.05)$ in the experimental group.

The spermatozoa with an abnormal acrosome (bloated acrosome, lack of acrosome) accounted for $45.78 \pm 3.52 \%$ of all abnormal sperm cells in the rats of the experimental group and $24.9 \pm 2.13 \%$ in control $(\mathrm{p}<0.05)$.

Combination of flagellar abnormality in the middle part with a drop on the flagellum was found in $0.99 \pm 0.17 \%$ of all abnormal cells in control and in $3.99 \pm 0.38 \%$ in experimental group $(\mathrm{p}<0.05)$.

Table 2.

\section{Identified anomalies in the development of gametes} (200 cells were counted in each animal)

\begin{tabular}{|l|c|c|c|}
\hline \multirow{2}{*}{ Indicators, absolute number of cells } & \multicolumn{2}{|c|}{ Group } & $\begin{array}{c}\text { Difference } \\
\text { between } \\
\text { groups, } \%\end{array}$ \\
\cline { 2 - 3 } & $\begin{array}{c}\text { Control } \\
(n=10)\end{array}$ & $\begin{array}{c}\text { Experimental } \\
(n=10)\end{array}$ & $28,4^{*}$ \\
\hline The end of the flagellum in the form of a loop & $12,1 \pm 1,37$ & $17,0 \pm 1,49$ & 6,4 \\
\hline $\begin{array}{l}\text { The presence of a cytoplasmic drop } \\
\text { on the flagellum }\end{array}$ & $12,7 \pm 1,34$ & $13,5 \pm 1,84$ & $75,2^{*}$ \\
\hline $\begin{array}{l}\text { Combination of flagellar anomaly } \\
\text { in the middle part with a drop on the flagellum }\end{array}$ & $2,0 \pm 0,67$ & $8,0 \pm 1,25$ & $45,6^{*}$ \\
\hline $\begin{array}{l}\text { Acrosome abnormality (swollen acrosome, } \\
\text { missing acrosome) }\end{array}$ & $49,8 \pm 2,82$ & $91,6 \pm 4,12$ & $100^{*}$ \\
\hline Swollen head & $1,2 \pm 0,63$ & - & $92,1^{*}$ \\
\hline Slim head & $1,6 \pm 0,52$ & $20,2 \pm 2,94$ & $83,3^{*}$ \\
\hline Big head & $3,4 \pm 0,70$ & $20,4 \pm 2,95$ & $84,2^{*}$ \\
\hline Inclined head & $3,2 \pm 0,92$ & $20,2 \pm 1,03$ & $31,0^{*}$ \\
\hline Cytoplasmic droplet at the base of the head & $13,8 \pm 1,32$ & $20,0 \pm 1,76$ & - \\
\hline Double tail & $3,8 \pm 0,79$ & $1,8 \pm 0,79$ & $100^{*}$ \\
\hline Wrinkled tail & $0,6 \pm 0,52$ & $20,4 \pm 1,07$ & $80,6^{*}$ \\
\hline Short tail & $1,0 \pm 0,82$ & $17,0 \pm 4,19$ & $97,1^{*}$ \\
\hline No tail & $105,2 \pm 5,75$ & $269,7 \pm 8,78$ & $94,1^{*}$ \\
\hline Total number of detected anomalies & $76,6 \pm 4,84$ & $130,1 \pm 5,92$ & $36,9^{*}$ \\
\hline Total number of abnormal cells & $1,37 \pm 0,03$ & $2,07 \pm 0,06$ & 33,8 \\
\hline TZI & \multicolumn{2}{|}{} \\
\hline
\end{tabular}

The remaining abnormalities of spermatozoa (swollen head, thin head, large head, bowed head, presence of a cytoplasmic drop at the base of the head, double tail, tail with fractures, short tail, and no tail) accounted for 0.9 to $10.2 \%$ in the control group, and 0.5 to $6.9 \%$ in the experimental group. 
TZI in control was lower (1.4) compared with that of the experimental group (2.07).

Despite the quite contradictory data concerning the parameters of the sperm quality [12], [17], [22], the researchers noted that male fertility directly depends on the frequency of morphological deviations of spermatozoa [21]. The mechanisms of morphological deviations of gametes formation also affect the sperm motility [14]. Our study confirmed the latter results.

We found in animals that the male reproductive system responds to simulated stressful conditions. Such a reaction may include a decrease in the total spermatozoa count in the appendage homogenate in the experimental rats compared with the control, and a decrease in the number of actively moving spermatozoa and an increase in the number of dead cells. We can assume it to decrease the fertilizing ability. In addition, morphological abnormalities detected as a cytoplasmic drop on the flagellum and the end of the flagellum as a loop belong to the group of abnormalities most common in infertile couples [20].

Abnormal forms of gametes were found also in both groups but more abundantly in the experimental group.

Similar changes, when exposed to various chronic stressors, were found in earlier studies [13].

\section{Conclusion}

In male rats exposed to stressors, the number of spermatozoa per volume of epididymal suspension was significantly lower compared to that in intact males.

The increase in the number of some abnormalities in the sperm morphology in male rats shows the effect of the simulated stress conditions under study.

A higher TZI was found in rats exposed to stressors accompanied by an increase both in the total number of abnormalities detected and in the number of abnormal cells.

Undoubtedly, changes in the ejaculate parameters in experimental animals under simulated stress depends on the strength and duration of the stress exposure. We have shown that even short-term but combined exposure to stressors leads to significant changes in the spermogram, and quantitative and qualitative parameters of the seminal fluid can be a convincing criterion of maladaptation processes in the body under the stress. Our preliminary results show the feasibility of further studies of the effects of combined stresses on male reproductive function.

Conflict of interest information. The authors declare that they have no conflicts of interest. 


\section{References}

1. Artifeksov S.B., Borodacheva I.V., Sergeev M.Yu. Problemy reproduktsii, 2017, vol. 23, no. 1, pp. 80-83. https://doi.org/10.17116/repro201723180-83

2. Barsukov A.A., Shcherbakov D.V., Lytkina S.V., Churin A.S. Sovremennye problemy nauki i obrazovaniya, 2018, no. 6, pp. 32. https://science-education. $\mathrm{ru} / \mathrm{ru} /$ article/view?id=28224

3. Bryukhin G.V., Sizonenko M.L., Kustavinova E.V. Problemy reproduktsii, 2014, no. 5, pp. 22-25. https://www.mediasphera.ru/issues/problemy-reproduktsii/2014/5/downloads/ru/031025-7217201454

4. Denisova T.G., Denisov M.S., Lezhenina S.V., Bushueva E.V., Lyalina T.S, Fedorov A.A. Acta Medica Eurasica, 2018, no. 1, pp. 15-21. http://acta-medica-eurasica.ru/single/2018/1/3/

5. Las'kov D.S., Bryukhin G.V., Sizonenko M.L., Alymov E.A. Problemy reproduktsii, 2014, no. 2, pp. 18-22. https://www.mediasphera.ru/issues/problemy-reproduktsii/2014/2/downloads/ru/031025-7217201425

6. Lutskiy D.L., Nikolaev A.A. Morfologicheskoe issledovanie eyakulyata: metod. posobie [Morphological study of ejaculate: method. manual]. Izd-vo AGMA, Astrakhan': Izd-vo Astrakh. gos. med. akad., 1999, 46 p.

7. Mirzakulov D.S. Osobennosti vliyaniya khlororganicheskikh soedineniy na fertil'nuyu funktsiyu muzhchin, prozhivayushchikh $v$ Oshskoy oblasti [Features of the influence of organochlorine compounds on the fertile function of men living in the Osh region]. Bishkek, 2014, 109 p.

8. Nitkin D.M., Rakevich M.V., Koleda A.G., Baturevich L.V., Yuraga T.M. Laboratornaya diagnostika Vostochnaya Evropa, 2018, vol. 7, no. 4, pp. 517-526.

9. Oganesyan M.A., Skuratovskaya L.N., Drozdov G.A. Patofiziologiya i sovremennaya meditsina materialy konferentsii [Pathophysiology and modern medicine conference proceedings]. 2004, p. 37.

10. Osadchuk L.V., Popova A.V., Kleshchev M.A., Osadchuk A.V. Rossiyskiy fiziologicheskiy zhurnal im. I.M. Sechenova, 2017, vol. 103, no. 8, pp. 940-951.

11. Pashkova E.Yu., Kalinchenko S.Yu. Effektivnaya farmakoterapiya, 2013, no. 1, pp. 26-31.https://umedp.ru/articles/muzhskoe_besplodie_v_xxi_veke_realii_i_ perspektivy_novye_vozmozhnosti_ispolzovaniya_kombinirovannoy.html

12. Popova A.V., Kleshchev M.A., Osadchuk A.V., Gutorova N.V., Osadchuk L.V. Vestnik Novosibirskogo gosudarstvennogo universiteta. Seriya: Biologiya, klinicheskaya meditsina, 2011, vol. 9, no. 3, pp. 47-54. https://nsu.ru/xmlui/ handle/nsu/4574

13. Potemina T.E., Kuznetsova S.V., Lyalyaev V.A. Sovrem. tekhnol. med., 2009, no. 2, pp. 23-26. http://www.stm-journal.ru/ru/numbers/2009/2/568 
14. Proshin S.N., Stepanov G.V., Novikova E.N., Bayramov A.A., Bychkov E.R., Shabanov P.D., Komyakov B.K. Andrologiya i genital'naya khirurgiya, 2010, vol. 11, no. 3, pp. 71-75.

15. Rukovodstvo VOZ po issledovaniyu i obrabotke eyakulyata cheloveka [WHO guidelines for the study and processing of human ejaculate]. https://apps. who.int/iris/bitstream/handle/10665/44261/97859051060905_rus.pdf?sequence $=34 \& u a=1$

16. Shevyrin A.A. Russkiy meditsinskiy zhurnal. Meditsinskoe obozrenie, 2018, vol. 2, no. 12, pp. 30-35. https://www.rmj.ru/articles/urologiya/Sovremennyy_ vzglyad_na_lechenie_narusheniy_mughskoy_fertilynoy_funkcii/

17. Arestova Inessa Y., Vladislav V Alekseev. Boar semen cytomorphology features after intramuscular injections of sedimin ${ }^{\circledR}$ and subsequent diet fortification by a zeolite-containing product. Biology and Medicine, 2014, vol. 6, no. 1, article ID: BM-003-14, 2014.

18. Council of Europe. European convention for the protection of vertebrate animals used for experimental and other scientific purpose. Strasbourg, 18.03.1986. http://www.worldlii.org/int/other/treaties/COETSER/1986/1.html

19. De Felice F., Marchetti C., Marampon F., Cascialli G., Muzii L. and Tombolini V. Radiation effects on male fertility. Andrology, 2019, vol. 7, no. 1, pp. 2-7. https://doi.org/10.1111/andr.12562

20. Jouannet P., Ducot B., Feneux D., Spira A. Male Factors and the Likelihood of Pregnancy in Infertile Couples. I. Study of Sperm Characteristics. Int. J. Androl., 1988, vol. 11, no. 5, pp. 379-394. https://doi.org/10.1111/j.1365-2605.1988.tb01011.x

21. Khan M.S, Ali I., Khattak A. M., Ullah A., Khan M.A., Javed A. Frequency of polyzoospermia and teratozoospermia in infertile men. Gomal J. Medical Science, 2006, vol. 4, no. 1, pp. 10-14. http://www.gjms.com.pk/index.php/journal/ article/view/77

22. Meeker J.D., Singh N.P., Hauser R. Serum concentrations of estradiol and free T4 are inversely correlated with sperm DNA damage in men from an infertility clinic. J. Androl., 2008, vol. 29, no. 4, pp. 140-146. https://doi.org/10.2164/ jandrol.107.004416

23. Swan S.H., Charlene Brazil, Erma Z. Drobnis, Fan Liu, Robin L. Kruse, Maureen Hatch, J. Bruce Redmon, Christina Wang, James W. Overstreet. Geographic differences in semen quality of fertile US males. Environmental Health Perspectives, 2003, vol. 111, no. 4, pp. 414-420. https://doi.org/10.1289/ehp.5927

24. Tomas Jambor, Hana Greifova, Jana Bistakova and Norbert Lukac. Endocrine Disruptors and Reproductive Health in Males. Endocrine Disruptors, Ahmed R. G., IntechOpen, 2018. https://doi.org/10.5772/intechopen.78538 


\section{Список литературы}

1. Артифексов С.Б., Бородачева И.В., Сергеев М.Ю. Мужская инфертильность - методы выявления и пути коррекции // Проблемы репродукции. 2017. T. 23, № 1. C. 80-83. https://doi.org/10.17116/repro201723180-83

2. Барсуков А.А., Щербаков Д.В., Лыткина С.В., Чурин А.С. Влияние факторов питания на показатели эякулята у молодых мужчин // Современные проблемы науки и образования. 2018. № 6. C. 32. https://science-education. $\mathrm{ru} / \mathrm{ru} / \mathrm{article} / \mathrm{view}$ ?id $=28224$

3. Брюхин Г.В., Сизоненко М.Л., Куставинова Е.В. Характеристика клеток Лейдига у потомства самок крыс с хроническим поражением печени различного генеза при действии иммобилизационного стресса // Проблемы репродукции. 2014. №5. С. 22-25. https://www.mediasphera.ru/issues/ problemy-reproduktsii/2014/5/downloads/ru/031025-7217201454

4. Денисова Т.Г., Денисов М.С., Леженина С.В., Бушуева Э.В., Лялина Т.С, Федоров А.А. Психо-эмоциональный стресс как фактор риска нарушений состояния репродуктивного здоровья // Acta Medica Eurasica. 2018. № 1. C. 15-21. http://acta-medica-eurasica.ru/single/2018/1/3/

5. Ласьков Д.С., Брюхин Г.В., Сизоненко М.Л., Алымов Е.А. Особенности морфофункциональных характеристик сперматозоидов у потомства самок крыс с экспериментальным поражением печени алкогольного генеза // Проблемы репродукции. 2014. №2. C. 18-22. https://www.mediasphera.ru/ issues/problemy-reproduktsii/2014/2/downloads/ru/031025-7217201425

6. Луцкий Д.Л., Николаев А.А. Морфологическое исследование эякулята: метод. пособие. Изд-во АГМА, Астрахань: Изд-во Астрах. гос. мед. акад., 1999. $46 \mathrm{c}$.

7. Мирзакулов Д.С. Особенности влияния хлорорганических соединений на фертильную функцию мужчин, проживающих в Ошской области: дис. канд. мед.наук. Бишкек, 2014. 109 с.

8. Ниткин Д.М., Ракевич М.В., Коледа А.Г., Батуревич Л.В., Юрага Т.М. Характеристика репродуктивного потенциала эякулята в зависимости от антропометрического статуса и метаболического состояния организма мужчин фертильного возраста // Лабораторная диагностика Восточная Европа. 2018. Т. 7, № 4. С. 517-526.

9. Оганесян М.А., Скуратовская Л.Н., Дроздов Г.А. Нарушение репродуктивной функции в условиях психоэмоционального стресса // Патофизиология и современная медицина материалы конференции. 2004. С. 37.

10. Осадчук Л.В., Попова А.В., Клещев М.А., Осадчук А.В. Региональная изменчивость показателей сперматогенеза и уровня репродуктивных гормо- 
нов у молодых мужчин Западной Сибири // Российский физиологический журнал им. И.М. Сеченова. 2017. Т. 103, № 8. С. 940-951.

11. Пашкова Е.Ю., Калинченко С.Ю. Мужское бесплодие в XXI веке - реалии и перспективы. Новые возможности использования комбинированной стимулирующей терапии гонадотропинами // Эффективная фармакотерапия. 2013. № 1. C. 26-31. https://umedp.ru/articles/muzhskoe_besplodie_v_xxi_ veke_realii_i_perspektivy_novye_vozmozhnosti_ispolzovaniya_ kombinirovannoy.html

12. Попова А.В., Клещёв М.А., Осадчук А.В., Гуторова Н.В., Осадчук Л.В. Морфологический анализ сперматозоидов и связь их аномалий с показателями спермограммы // Вестник Новосибирского государственного университета. Серия: Биология, клиническая медицина. 2011. Т. 9, № 3. С. 47-54. https://nsu.ru/xmlui/handle/nsu/4574

13. Потемина Т.Е., Кузнецова С.В., Ляляев В.А. Изменение параметров семенной жидкости самцов белых крыс при различных видах экспериментального стресса // Соврем. технол. мед. 2009. №2. С. 23-26. http://www. stm-journal.ru/ru/numbers/2009/2/568

14. Прошин С.Н., Степанов Г.В., Новикова Е.Н., Байрамов А.А., Бычков Е.Р., Шабанов П.Д., Комяков Б.К. Функциональная характеристика сперматозоидов и индекс тератозооспермии // Андрология и генитальная хирургия. 2010. T. 11, № 3. С. 71-75.

15. Руководство ВОЗ по исследованию и обработке эякулята человека. https://apps.who.int/iris/bitstream/handle/10665/44261/97859051060905_rus. pdf? sequence $=34 \& u a=1$

16. Шевырин А.А. Современный взгляд на лечение нарушений мужской фертильной функции // Русский медицинский журнал. Медицинское обозрение. 2018. T. 2, № 12. C. 30-35. https://www.rmj.ru/articles/urologiya/Sovremennyy_ vzglyad_na_lechenie_narusheniy_mughskoy_fertilynoy_funkcii/

17. Arestova Inessa Y., Vladislav V Alekseev. Boar semen cytomorphology features after intramuscular injections of $\operatorname{sedimin}{ }^{\circledR}$ and subsequent diet fortification by a zeolite-containing product // Biology and Medicine, 2014, vol. 6, no. 1, Article ID: BM-003-14, 2014.

18. Council of Europe. European convention for the protection of vertebrate animals used for experimental and other scientific purpose. Strasbourg, 18.03.1986. http://www.worldlii.org/int/other/treaties/COETSER/1986/1.html

19. De Felice F., Marchetti C., Marampon F., Cascialli G., Muzii L. and Tombolini V. Radiation effects on male fertility // Andrology, 2019, vol. 7, no. 1, pp. 2-7. https://doi.org/10.1111/andr.12562 
20. Jouannet P., Ducot B., Feneux D., Spira A. Male Factors and the Likelihood of Pregnancy in Infertile Couples. I. Study of Sperm Characteristics // Int. J. Androl., 1988, vol. 11, no. 5, pp. 379-394. https://doi.org/10.1111/j.1365-2605.1988. tb01011.x

21. Khan M.S, Ali I., Khattak A. M., Ullah A., Khan M.A., Javed A. Frequency of polyzoospermia and teratozoospermia in infertile men // Gomal J. Medical Science, 2006, vol. 4, no. 1, pp. 10-14. http://www.gjms.com.pk/index.php/journal/ article/view/77

22. Meeker J.D., Singh N.P., Hauser R. Serum concentrations of estradiol and free T4 are inversely correlated with sperm DNA damage in men from an infertility clinic // J. Androl., 2008, vol. 29, no. 4, pp. 140-146. https://doi.org/10.2164/ jandrol.107.004416

23. Swan S.H., Charlene Brazil, Erma Z. Drobnis, Fan Liu, Robin L. Kruse, Maureen Hatch, J. Bruce Redmon, Christina Wang, James W. Overstreet. Geographic differences in semen quality of fertile US males // Environmental Health Perspectives, 2003, vol. 111, no. 4, pp. 414-420. https://doi.org/10.1289/ehp.5927

24. Tomas Jambor, Hana Greifova, Jana Bistakova and Norbert Lukac. Endocrine Disruptors and Reproductive Health in Males // Endocrine Disruptors, Ahmed R. G., IntechOpen, 2018. https://doi.org/10.5772/intechopen.78538

\section{DATA ABOUT THE AUTHORS}

Inessa Y. Arestova, Candidate of Biological Sciences, Associate Professor of the Department of Bioecology and Chemistry

I.Y. Yakovlev State Pedagogical University of Chuvash

K. Marx Str., 38, Cheboksary, 428000, Russian Federation nessizz@rambler.ru

ORCID: 0000-0002-4716-2141

ResearcherID: $A A G-7270-2019$

Scopus Author ID: 56377067300

Evgeniya G. Sharonova, Candidate of pedagogical sciences, Associate Professor, Head of the Department of Biology and Fundamentals of Medical Knowledge

I.Y. Yakovlev State Pedagogical University of Chuvash

K. Marx Str., 38, Cheboksary, 428000, Russian Federation

evgenija-sharonova@rambler.ru

ORCID: 0000-0002-4155-7118

ResearcherID: $A A Q-9484-2020$ 
Marina Y. Kupriyanova, Candidate of biological sciences, Associate Professor, Head of the Department of Bioecology and Chemistry

I.Y. Yakovlev State Pedagogical University of Chuvash

K. Marx Str., 38, Cheboksary, 428000, Russian Federation

sofmar@bk.ru

ORCID: 0000-0003-3247-8052

ResearcherID: $A A Q-9443-2020$

\section{ДАННЫЕ ОБ АВТОРАХ}

Арестова Инесса Юрьевна, кандидат биологических наук, доцент, доцент кафедры биоэкологии и химии

Федеральное государственное бюджетное образовательное учреждение выстего образования «Чувашский государственный педагогический университет им. И.Я. Яковлева»

ул. К. Маркса, 38, г. Чебоксары, 428000, Российская Федераџия nessizz@rambler.ru

Шаронова Евгения Геннадьевна, кандидат педагогических наук, доцент, заведующая кафедрой биологии и основ медицинских знаний Федеральное государственное бюджетное образовательное учреждение выстего образования «Чувашский государственный педагогический университет им. И.Я. Яковлева»

ул. К. Маркса, 38, г. Чебоксары, 428000, Российская Федераџия evgenija-sharonova@rambler.ru

Куприянова Марина Юрьевна, кандидат биологических наук, доцент, заведующая кафедрой биоэкологии и химии

Федеральное государственное бюджетное образовательное учреждение выстего образования «Чувашский государственный педагогический университет им. И.Я. Яковлева»

ул. К. Маркса, 38, г. Чебоксары, 428000, Российская Федераџия sofmar@bk.ru 